\title{
Utility of Rain Water Harvesting System in the Present Scenario of Gwalior City: A Case Study
}

\author{
P. K. Jain \\ School of Studies in Earth Science, Jiwaji University, Gwalior (MP), India. PIN- 474011
}

\begin{abstract}
Water is elixir of the life, in the geological term it is called as mineral. It should be conserved and preserved in all the way or through adopting any "Rain water harvesting system". Rain water is the only source of the fresh water, so that it can be collected during the rainy season to store for present \& future use well. The rain water is collected only through to make the various "Rain Water Harvesting Structures (RWHS)" as per suitability of the site. Generally two types of RWHS are designed for same, as they are the part of any rain water harvesting system, such as (i) roof top rain water harvesting system and (ii) surface rain water harvesting system. In the Gwalior city every year, ground water level goes down approx. Imeter in the present time, indicating the over exploitation of it and lack of normal annual rain fall, causing insufficient recharging the same, 20 years ago it was easily available from $60-80$ feet below the earth surface, now days it goes down and down. This situation may be changed, if every commercial / residential as well as big house / offices / school-colleges or any other type of settlement must be adopted at least one "Rain Water Harvesting System" within their premises, to save and conserve the rain water for their timely use by every citizen of the city and other part of the country also. It should be the motto of every one citizen of India. Ground water level may be increased upward gradually through recharging of aquifers, which are situated at different level within the earth by the said system positively. A case study of Abhiyank Estate, University Road, Thatipur, Gwalior tells, how Ground Water level is increased gradually after use of surface rain water runoff of the premises, through "surface rain water harvesting structure (SRWHS)", which was made in the year of 2008 within campus.
\end{abstract}

Keywords: Rain Water Harvesting System, RWHS, Aquifers, Mineral and SRWHS

\section{Introduction}

Once upon a time, the Hindi poet was said regarding the water as "Rahiman Pani Rakhiye, Bin Pani Sab Soon" [1]. The aforesaid lines must be followed by all the human beings of this planet to sustain the life on the present earth in the modern high-tech world positively. Rain water is the only source of fresh water [2] and rain water harvesting system is the only activity to direct collection of rain water through rain water harvesting structures (RWHS), it can be stored for direct use or can be recharged into the "ground water aquifer" for future use well.

\section{Area of Study}

The present area of study, namely "Abhiyank Estate", University Road, Thatipur, Gwalior (M.P.), PIN-474011, India is lying in between the Cartesian Coordinates $26^{\circ} 12^{\prime}$ $39.9^{\prime \prime}$ to $26^{\circ} 12^{\prime} 41.4^{\prime \prime} \mathrm{N}$ and $78^{0} 11^{\prime} 57.8^{\prime \prime}$ ' to $78^{\circ} 11^{\prime} 59.3^{\prime}$ ', E, covering approximately $1050 \mathrm{~m}^{2}$ area (Fig. 1). The said premise is maintained by "Abhiyank Estate Society, Gwalior since beginning well.

\section{Methodology}

Following data have been incorporated to find out the results of the study -

\subsection{Google earth image}

Google earth images [3] have been used, to find out the physical location and catchment area of the investigated site under the study.

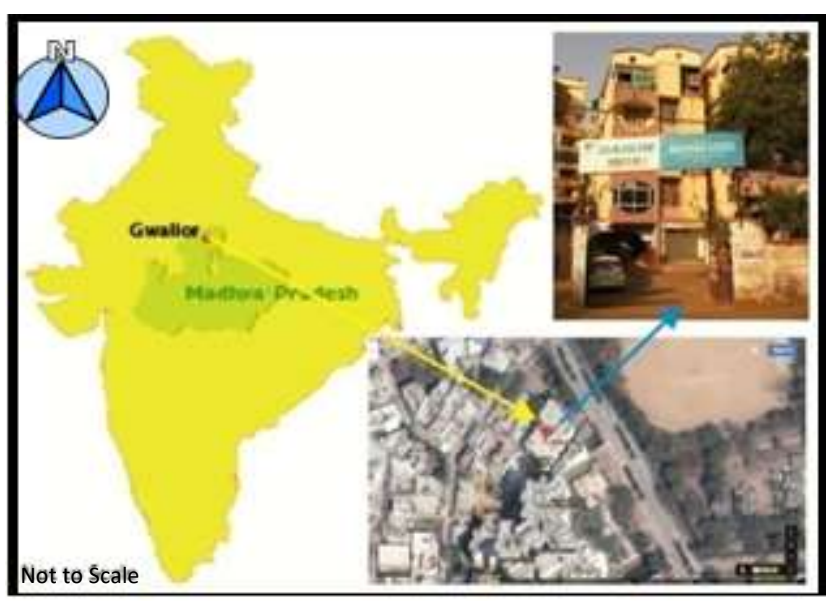

Figure 1: Location and approach map of study area

\subsection{GPS data}

Garmin make, e-trax vista Hcx model has been used to locate the study area (Cartesian Coordinates in the form of $\mathrm{x}$ and y) globally.

\subsection{Resistivity survey data:}

DDR-3 (IGIS, Hyderabad make) [4] resistivity meter has been used to record the geophysical data of the investigated site well.

\subsection{Old and running tube well data:}

Field data of old and running tube well of "Abhiyank Estate" [5] have been used. 


\section{International Journal of Science and Research (IJSR) \\ ISSN (Online): 2319-7064}

Index Copernicus Value (2016): 79.57 | Impact Factor (2015): 6.391

\subsection{Rain water harvesting structure (RWHS)}

Details of surface rain water harvesting structure (SRWHS), as present within the premises of "Abhiyank Estate" has been noted and used to find out the result of the study area.

\section{Rain Water Harvesting System:}

Rainwater harvesting means capturing the rain where it falls or capturing the runoff and taking measures to store that water and keep it clean [7]. It is the two component system, comprises by such as natural and manmade component, the whole system is called as rain water harvesting system. The system works for collecting, conveying and storing water from the rainfall during the rainy seasons in the area, for the use of present \& future purpose of all the living things on the earth as well as to sustain the life on the same.

\subsection{Natural Component}

Rain is the natural component of the system [8], generally falls in very large amount on the earth surface in the rainy season only. Rain is the only source of the water, so that it must be collected and store simultaneously through rain water harvesting system well, to meet out the daily as well as the future need of water of the society. Source of rain can be understand by the water cycle (Fig. 2), how it works in the nature as follows-

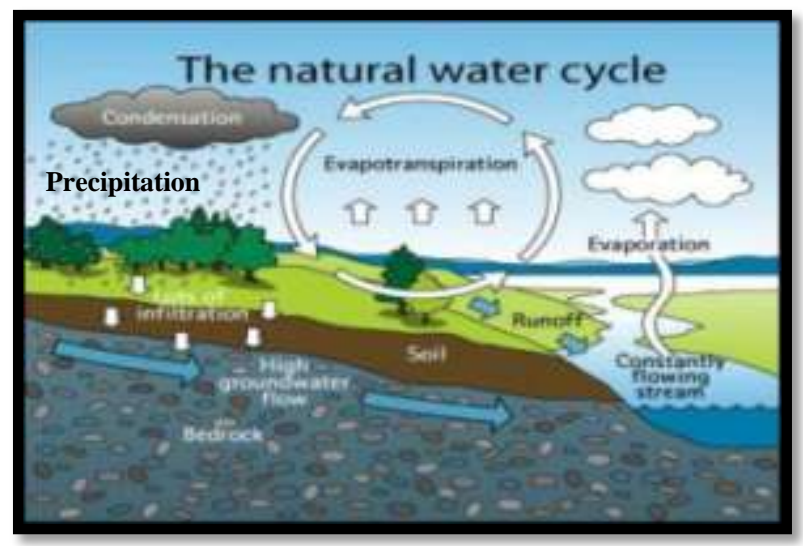

Figure 2: Water Cycle, Model Figure [6]

\subsection{Manmade Component}

As its name, it is made or design by the experts of this field, it is a structure as made by man, to collect and store the rain water during the rainy season. The whole component comprises by catchments, gutters / channels, down pipes, flushing pips, filter unit, storage tanks and some supporting natural and artificial materials. Generally it is made according to suitability of the site for rain water harvesting.

\subsection{Types Of Rain Water Harvesting System:}

Two type of rain water harvesting system are designed in the form of rain water harvesting structures (RWHS) such as -

\subsubsection{Roof Top Rain Water Harvesting Structure (RTRWHS)}

This system is designed to collect the roof top catchment area rain fall water and simultaneously store / settle the same to recharge the ground water of the premises etc. It is generally designed (Fig. 3) by the experts to see the particular building structure, roof area and open space around the same.

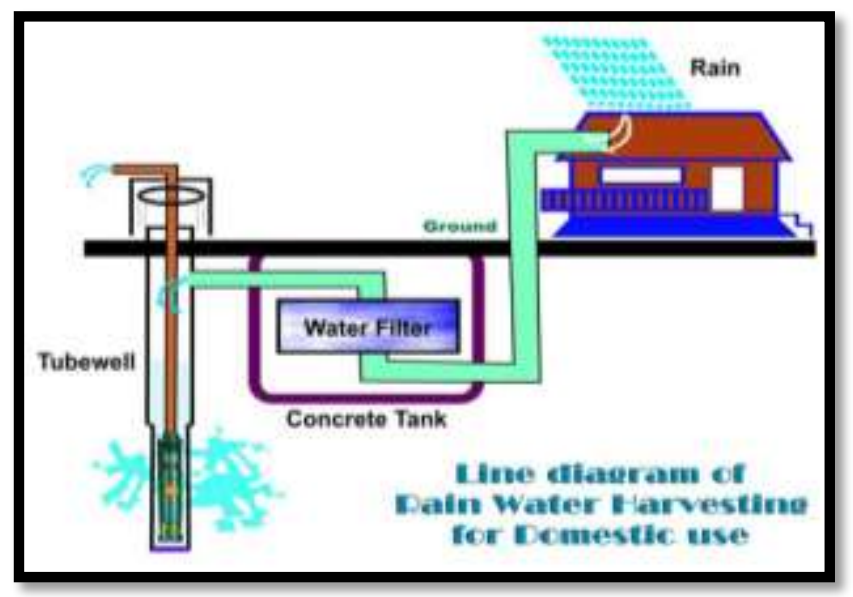

Figure 3: Model diagrams of roof top rain water harvesting structure [6].

\subsubsection{Surface Rain Water Harvesting Structure (SRWHS)}

This structure is designed after calculation of the surface rain water runoff as available at the particular site for RWHS, to store and recharge the ground water as available within the shallow and deep sheeted aquifers in the particular area/premises etc. Some popular surface rain water harvesting structures (Fig. 4A, 4B, 4C, 4D) [6] are namely Nala Bandh/Check Dam, Harvesting Pits, Ponds, Weirs, Trenches, Dug wells, Recharging wells, Recharging Shafts, Lateral shafts with bore well (Fig. 5) etc.

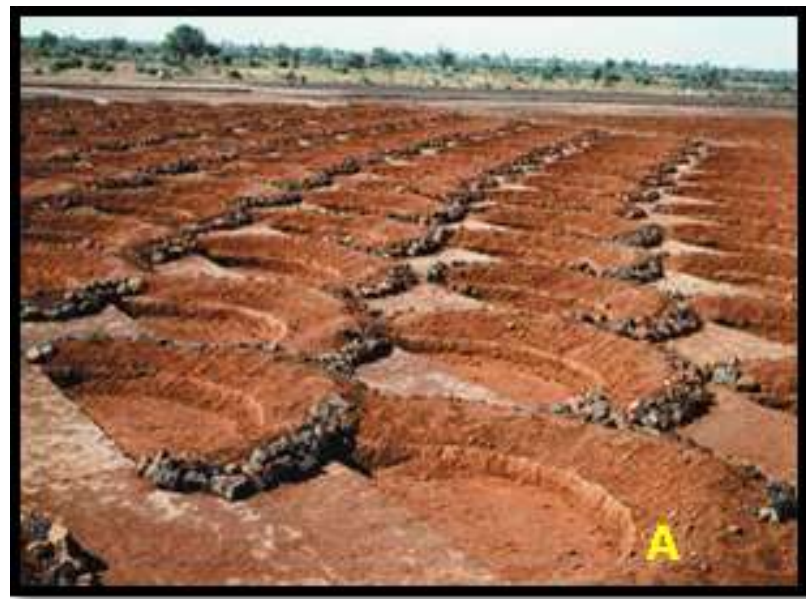

Figure 4 A: Series of Recharging pits 


\section{International Journal of Science and Research (IJSR) \\ ISSN (Online): 2319-7064}

Index Copernicus Value (2016): 79.57 | Impact Factor (2015): 6.391

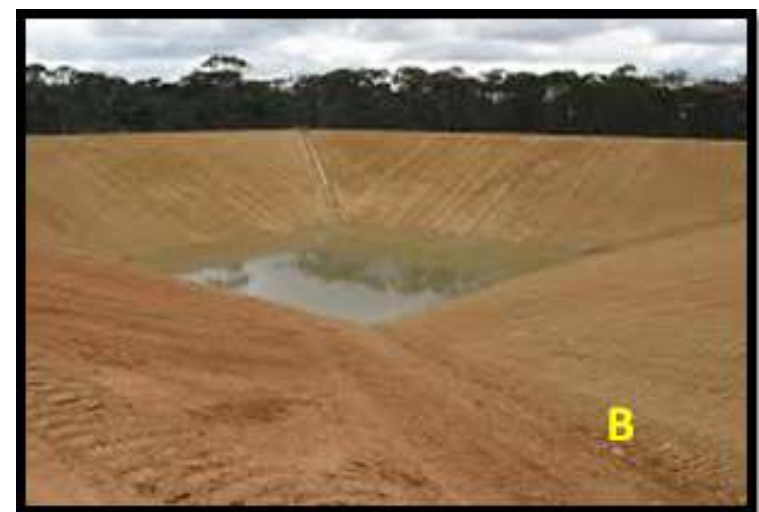

Figure 4 B: Recharging pit

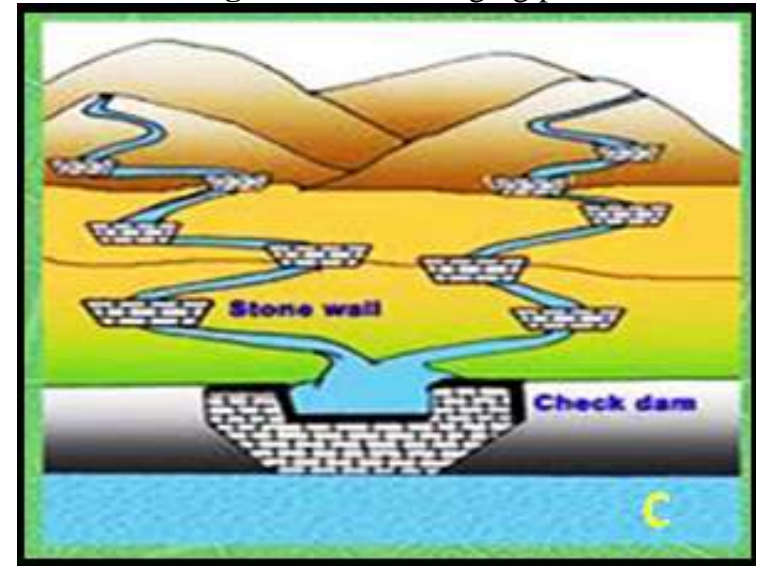

Figure 4 C: Check dam

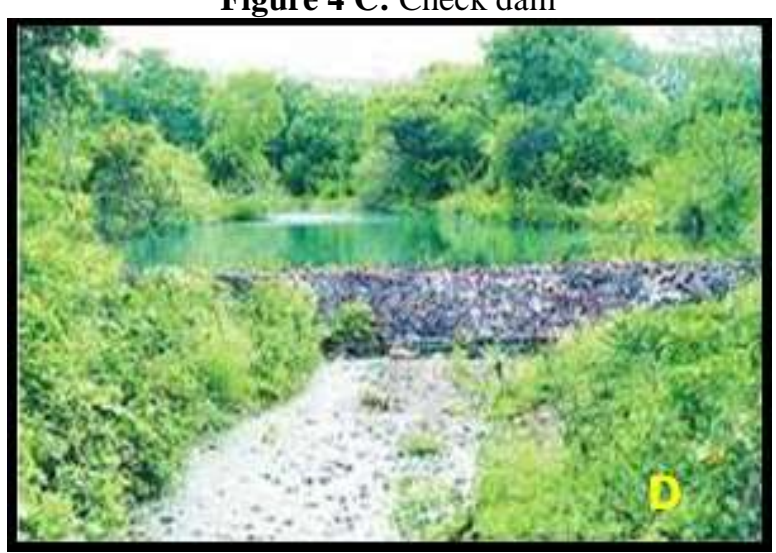

Figure 4 D: Weir

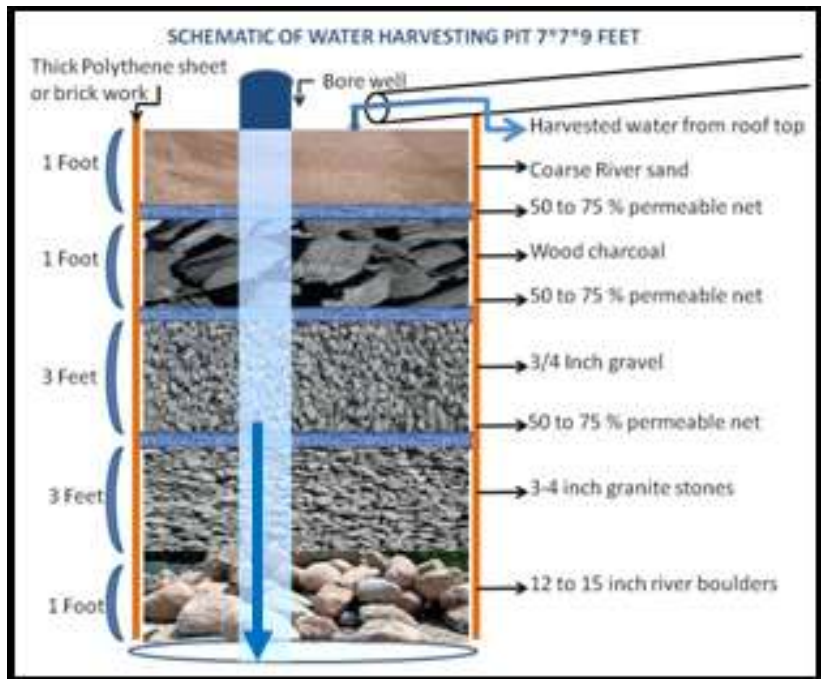

Figure 5: Lateral Shaft with Recharging Bore Well [6].

\section{Case Study}

Abhiyank Estate, University Road, Thatipur, Gwalior (M.P.), India has been taken as study area, where the surface rain water harvesting structure (SRWHS) had been made to recharge the running tube well of premise well.

\subsection{History}

The Abhiyank Estate building was completed in the year of 1999, it has 32 flats and 4 commercial units within, Lying in between the Cartesian Coordinates $26^{\circ} 12^{\prime} 39.9^{\prime}$ ' to $26^{\circ} 12^{\prime}$ 41.4' $\mathrm{N}$ and $78^{\circ} 11^{\prime} 57.8^{\prime \prime}$ to $78^{\circ} 11^{\prime} 59.3^{\prime \prime} \mathrm{E}$, covering approximately $1050 \mathrm{~m}^{2}$ area, occupancy- $100 \%$, at a time 30 families are residing within the apartment.

\subsection{Water Supply}

Building has self running "Tube Well", as well situated within the premises at building lawn (Fig. 6), which was dug in the year 2004, depth of the bore well is 132 feet, type of well ordinary, present yield approximate 1.5" continued without air.

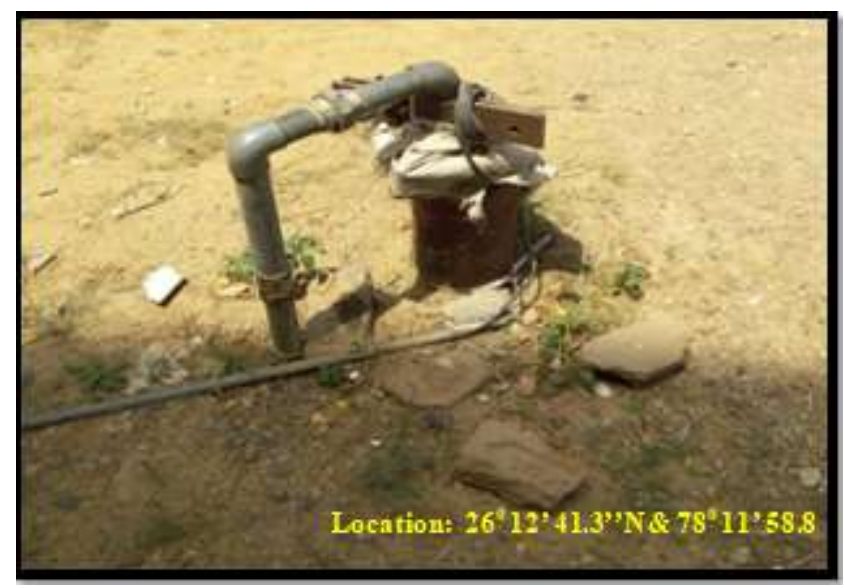

Figure 6: Running Tube Well

\subsection{Old Tube Well}

Two old tubes well were also digging in the years 1997 (Fig.7) and 1999 (Fig.8). Base line information about the all bore wells of Abhiyank Estate is given in table 1.

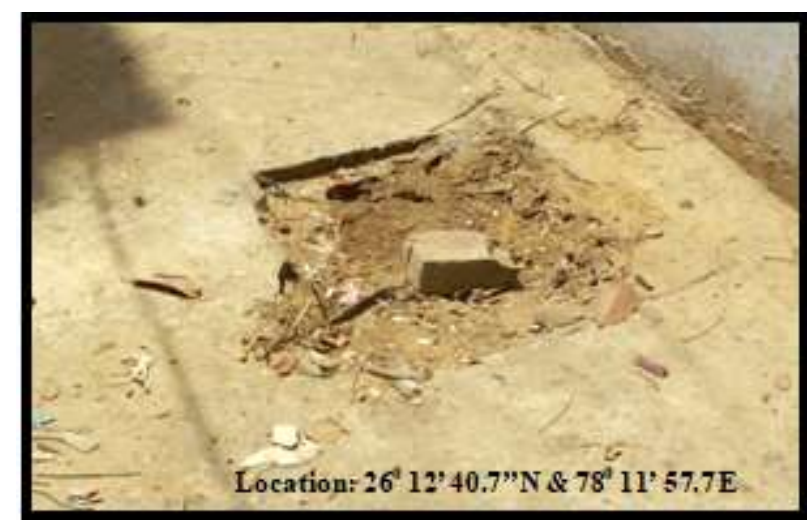

Figure 7: Old Tube Well -1

Volume 6 Issue 12, December 2017 www.ijsr.net 


\section{International Journal of Science and Research (IJSR) \\ ISSN (Online): 2319-7064}

Index Copernicus Value (2016): 79.57 | Impact Factor (2015): 6.391

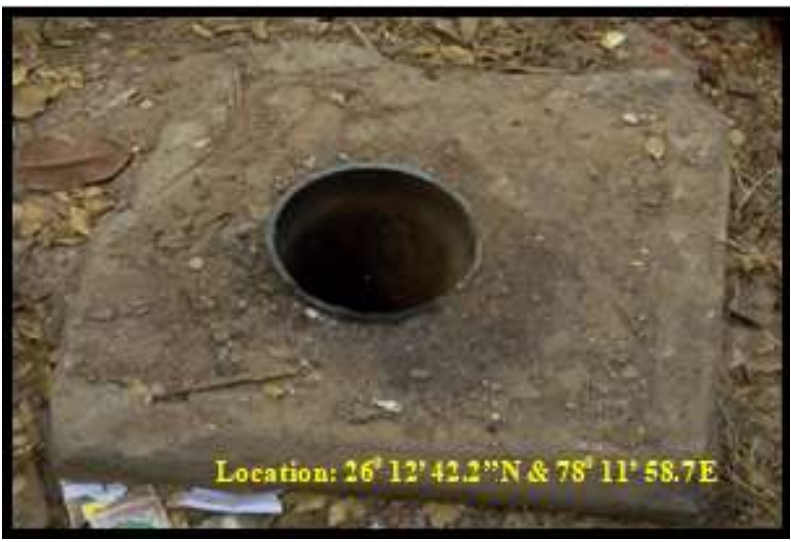

Figure 8: Old Tube Well -2

Table 1: Base line information about the tube wells.

\begin{tabular}{|c|c|c|c|c|c|c|c|}
\hline $\begin{array}{c}\text { S. } \\
\text { No. }\end{array}$ & $\begin{array}{c}\text { Type of } \\
\text { Well }\end{array}$ & $\begin{array}{c}\text { Year } \\
\text { of } \\
\text { Est. }\end{array}$ & $\begin{array}{c}\text { Depth } \\
\text { \& Dia. }\end{array}$ & $\begin{array}{c}\text { Past } \\
\text { yield }\end{array}$ & $\begin{array}{c}\text { Present } \\
\text { Yield }\end{array}$ & $\begin{array}{c}\text { Present } \\
\text { Status }\end{array}$ & Remark \\
\hline 1 & Ordinary & 1997 & $80^{\prime}, 5^{\prime \prime}$ & 2" & Nil & Dry & Old Well \\
\hline 2 & Ordinary & 1998 & $99^{\prime}, 5^{\prime \prime}$ & $2.25^{\prime \prime}$ & Nil & Dry & Old Well \\
\hline 3 & Ordinary & 2004 & $132^{\prime}, 7^{\prime \prime}$ & $2.50^{\prime \prime}$ & $1.50^{\prime \prime}$ & Good & $\begin{array}{c}\text { Running } \\
\text { Tube Well }\end{array}$ \\
\hline
\end{tabular}

\subsection{Water Requirement}

Over head tank of 25,000.00 litres capacity is situated at the top of the premise to meet out the daily need of water (Table 2), for all the resident of Abhiyank Estate. Water consumption per person has been calculated on the following bases-

i. Total Residential Unit (Flat): $\quad 36$.

ii. No. of Family Residing at a time: $\quad 30$.

iii. No. of Person / Family:

04.

iv. Total No. of Person ( 30 X 4):

120.

v. Water Requirement in Litres*: (table 2).

Table 2: Water Requirement

\begin{tabular}{|c|c|c|c|c|c|}
\hline Drinking & $\begin{array}{c}\text { Other } \\
\text { Domestic Use }\end{array}$ & $\begin{array}{c}\text { No. of } \\
\text { Person }\end{array}$ & $\begin{array}{c}\text { Per } \\
\text { day }\end{array}$ & $\begin{array}{c}\text { Total in } \\
\text { Month }\end{array}$ & Remark* \\
\hline 10 & 65 & 01 & 75 & 2250 & Approximately \\
\hline
\end{tabular}

\subsection{Rain Water Harvesting Structure (RWHS):}

Surface rain water harvesting structure (SRWHS) has been made at the site of investigation (Fig. 9). Section graph of SRWHS and dimension of recharging pit (10 X 4 X 8 feet) are shown in Fig. 10. Catchment area and runoff zone are showing in the image Figs. $11 \& \mathbf{1 2}$ respectively.

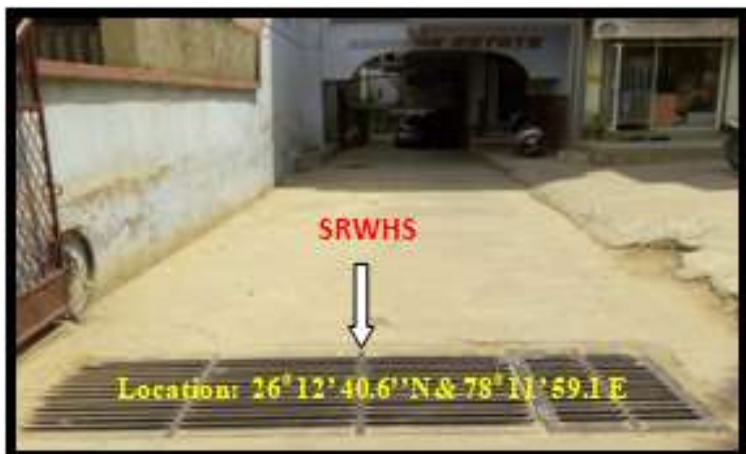

Figure 9: Surface rain water harvesting structure

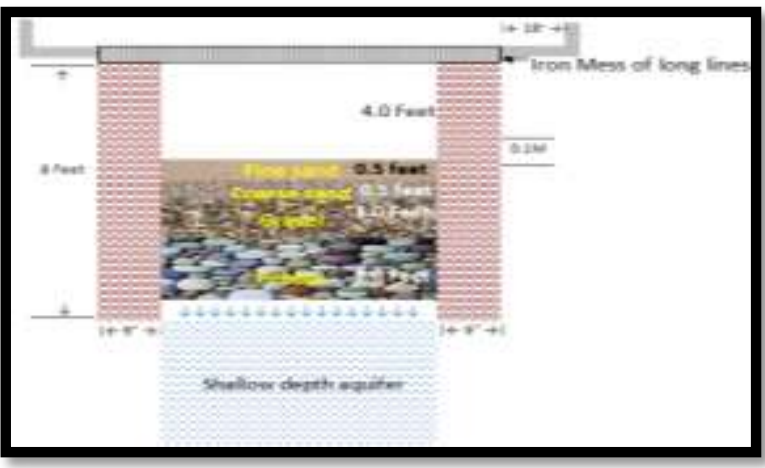

Figure 10: Section graph of SRWHS

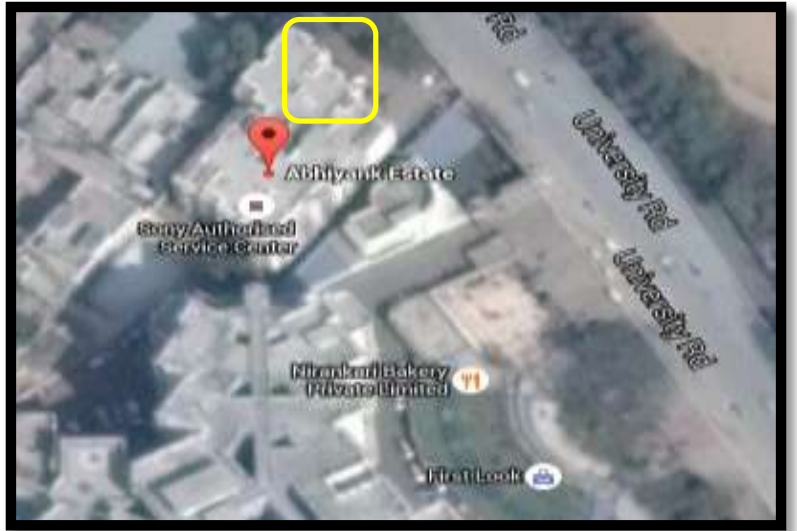

Figure 11: Image shows catchment area in rectangle.

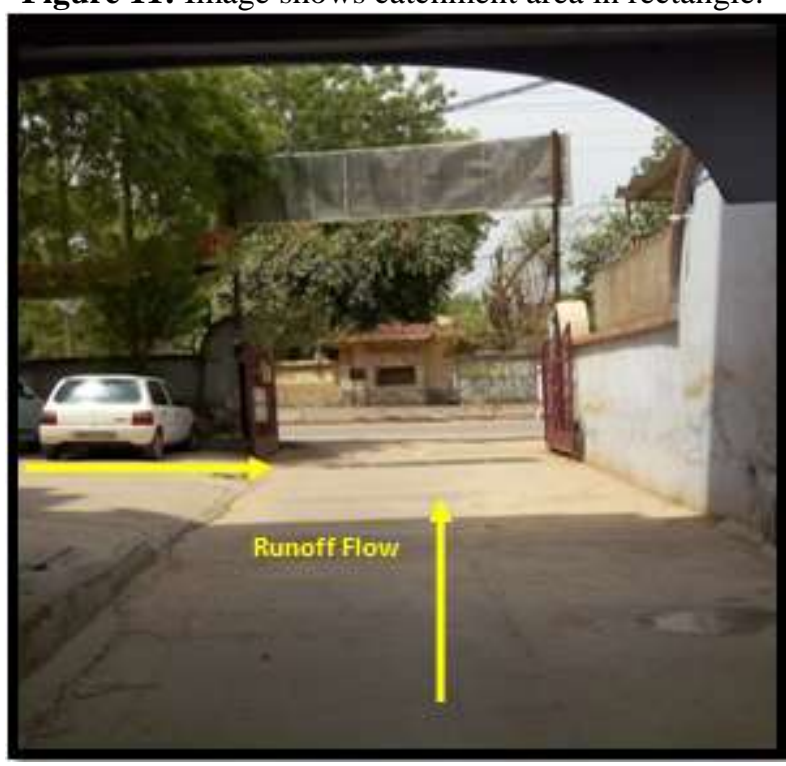

Figure 12: Runoff zone.

\subsection{Resistivity Survey Data}

To know the aquifer position (water bearing rock) at the investigated site, one geophysical survey was conducted [4] successfully in the form of VES (Vertical Electrical Sounding) by the resistivity meter (DDR-3), to find out the suitability of site for SRWHS. The measured resistivity curve and expected layers for same are showing in the Figs. 13 and 14 respectively.

Volume 6 Issue 12, December 2017 www.ijsr.net 


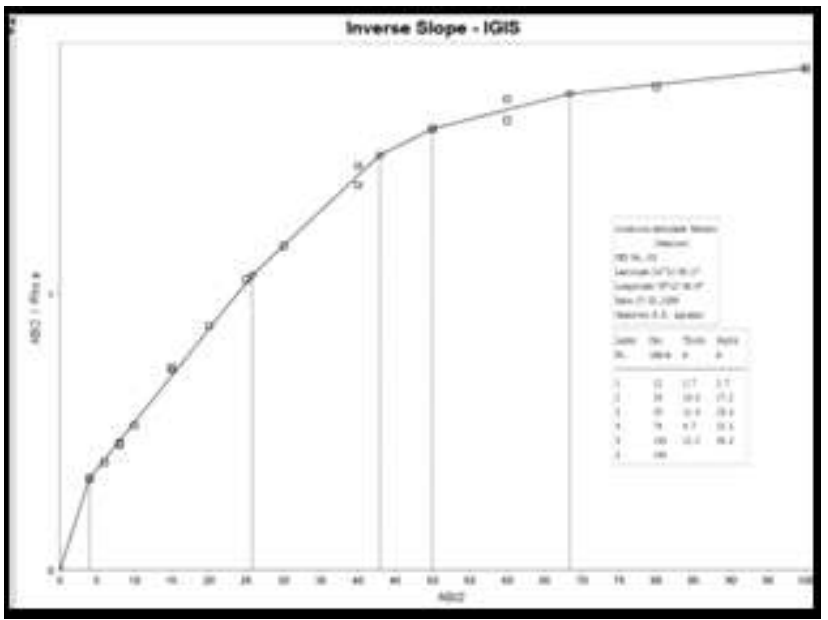

Figure 13: Resistivity Curve / VES.

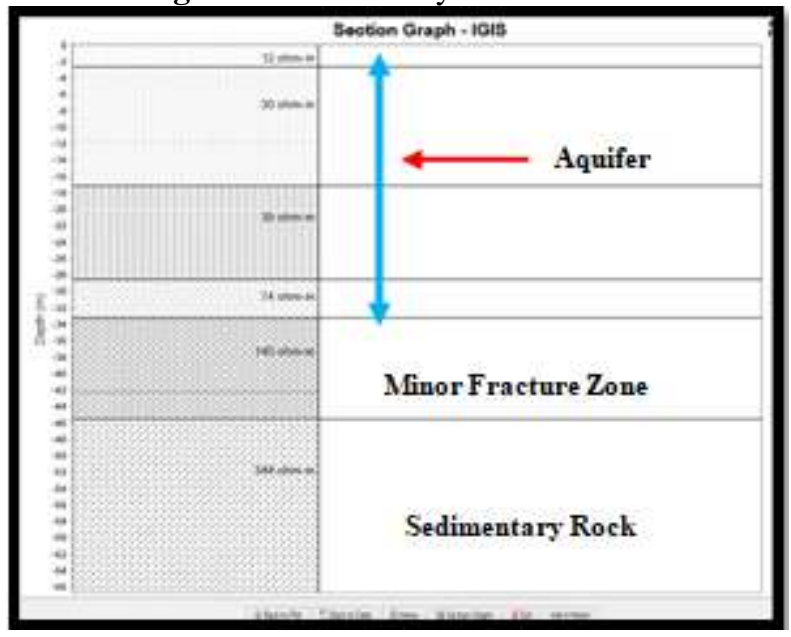

Figure 14: Expected Layers in meter.

\section{Result and Discussions}

Surface Rain Water Harvesting Structure (SRWHS) of Abhiyank Estate was made during the month of March, 2008 for surface runoff settlement through the said SRWHS, to recharge the shallow depth aquifer as well present at the harvesting site (Fig. 14), before the installation of the SRBHS within premises, initially yield of running bore well was low to moderate $(<1.25$ " of water), and some time water comes with air during the summer period, so that, residents of Abhiyank Estate have get the required water from the bore well after giving some time interval.

After two continuous year of rains, residents of Abhiyank Estate are find wonderful result from the installed SRWHS, yield of running bore well is increased from $<1.25$ " to $>2.00$ " of water (Apprx. 600-800 Gallon Per Hours), water comes from the tube well continuously throughout the year without any air or interruption through building SRWHS, Society of Estate has maintained the required yield of water from the present and running tube well. In present time, yield of the said tube well is slightly decreased ( $<>1.50$ " of water ) due to decrease of ground water table in the area, increased automatically after normal rain falls on the area through SRWHS well.

\section{Conclusions}

Now days in the Gwalior City, due to over exploitation of water and lack of normal rain falls [10], the ground water label is going down and down per year continuously. Water table is also going to down simultaneously. Deforestation, population, over consumption of water, increasing of temperature and wastage of this natural product are the main causes of same, Water is also called as Mineral [11], it must be conserve and manage timely.

\section{Why Rain Water Harvesting Structure (RWHS) Should Be Compulsory}

At the dawn of $21^{\text {st }}$. Century, numerous countries, including India, are facing a rapidly increasing water crisis. All major metros today face acute water shortages and the situation is even worse in rural areas. Thousands of Indian Villages still do not have a local source of drinking water. Women have to walk many miles to collect a pot of drinking water [12].

The afore said situation may be changed, if every commercial / residential as well as big houses / offices / school-colleges or any other type of settlement must be installed at least one "Rain Water Harvesting Structure" within their premises to save and conserve the rain water, for their timely use by every citizen of the city and from other part of our country also. It should be the motto of every citizen of India. Ground water level may be increased upward gradually through recharging of aquifers, which are situated at different level within the earth by the said system positively.

\section{Important Steps To Be Remembered Before Harvesting The Rain Water}

Harvested rain water is used for direct usage or for recharging aquifers, it is most important to ensure that the rain water should be free from pollutants. Following precautionary measures should be taken while harvesting rain water [9]:-

(a) Roof or terraces uses for harvesting should be clean, free from dust, algal plants etc.

(b) Roof should not be painted since most paints contain toxic substances and may peel off.

(c) Do not store chemicals, rusting iron, manure or detergent on the roof.

(d) Nesting of birds on the roof should be prevented.

(e) Terraces should not be used for toilets either by human beings or by pets.

(f) Provide gratings at mouth of each drainpipe on terraces to trap leaves debris and floating materials.

(g) Do not use polluted water to recharge ground water.

(h) Ground water should only be recharged by rain water.

(i) Before recharging, suitable arrangements of filtering should be provided.

(j) Filter media should be cleaned before every monsoon season.

(k) During rainy season, the whole system (roof catchment, pipes, screens, first flush, filters, tanks) should be 


\section{International Journal of Science and Research (IJSR) \\ ISSN (Online): 2319-7064 \\ Index Copernicus Value (2016): 79.57 | Impact Factor (2015): 6.391}

checked before after each rain and preferably cleaned after every dry period exceeding a month.

(1) At the end of dry season and just before the first shower of rain is anticipated, the storage tank should be scrubbed and flushed off all sediments and debris.

\section{Acknowledgement}

Author expresses his sincere gratitude to Professor S. N. Mohapatra, head, School of Studies in Earth science, Jiwaji University, Gwalior (M.P.) for valuable suggestions and providing all necessary facilities to compile the work. Author is also thankful to Mr. Rajendra Kumar Agrawal, hydro- geologist, Gwalior for acquiring the resistivity data of the investigated site. Thankful to "Abhiyank Estate Society" Gwalior for permission regarding all about the said case study. Thanks are also gone to the Google websites to acquire the images of the Abhiyank Estate, for showing the location and catchment area of surface runoff from their satellite well.

\section{References}

[1] Rahim, "Rahim ke dohe", Bharat - Darshan, Hindi Magazine (ISSN 2423-0758), 2/156, Universal drive, Henderson, Waitakere-0610, Auckland (New Zealand), 2015-16.

[2] Gautam Banerjee, "Rain Water harvesting", U P Jal Nigam, Lucknow, U.P., ppt., on Google, access in 2015.

[3] www.google earth, access on 2016.

[4] R. K. Agrawal, "Investigation of Ground Water", 98 Gayatri Vihar, Thatipur, Gwalior (M.P.), e-mail: aigw2004@yahoo.com, 2008.

[5] Abhiyank Estate, "Abhiyank Estate Society", University road, Thatipur, Gwalior (M.P.), PIN - 474011, established in year 1998-99.

[6] www.google images.

[7] Mbugua, J., "Rain water harvesting", URL: http://www.irc.nl/redir/content/download/128508/35087 9/file/TP40_7\%20Rain\%20water\%20harvesting.pdf. In: SMET, J., van WIJK, Ch. (2002): Small Community Water Supplies: Technology, people and partnership (=Technical Paper no 40). Available from: http://www.irc.nl/page/1917, 2002: 7.

[8] P. K. Jain, "Rain Water Harvesting Structures: A Business Opportunity", Technology, Innovation Management and Entrepreneurship Development (ISBN: 978-81-748-793-2), Editor- R. K. Pandit and D. K. Sharma, Radha Publications, New Delhi-110002, pp 302, 2017.

[9] Madhya Pradesh Pollution Control Board, "Rain Water Harvesting”, http://www.mppcb.nic.in/rwh.htm, pp 1-6, accessed on 28.07.2015.

[10] P. K. Jain, "Various Factors Responsible for Extreme Climatic Fluctuations in and around the Gwalior City", Frontiers in Environmental Research (ISBN: 978-9380525-71-6), Editor- Dr. Anish Chandra Pandey, Academic Excellence, New Delhi-110059, India, pp 102-116, 2012.

[11]H. H. Read, "Rutleys Elements of Mineralogy", $26^{\text {th }}$. Edition, CBS Publishers \& Distributors, 485, Jain
Bhawan, Bhola Nath Nagar, Shahadra, Delhi- 110032, India, pp 3, 1984.

[12] Anil Agarwal, short technical course on "Urban Rainwater Harvesting Techniques", Centre for Science and Environment, New Delhi, A CSE training programme ( October 4-7, 2006), pp 2, 2006.

\section{Author Profile}

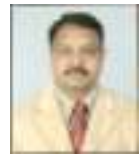

Dr. P.K. Jain did M.Sc., Ph.D. in Geology from Barkatullah University, Bhopal in 1988 and 1992 respectively. He has published more than 22 research papers in the various field of Geology, Remote Sensing \& GIS on both National and International level. Moreover, he is RQP (Recognized Qualified Person) for the preparation of mining plan and mining scheme by Indian Bureau of Mines (IBM), Govt. of India. At present, he is working as Assistant Professor, at Centre of Remote Sensing and GIS, School of Studies in Earth Science, Jiwaji University, Gwalior (M.P.), India, Mob. 09425360247 